\title{
Sustainable Innovation Strategy and Role of Learning Organization in Improving Business Unit Performance Empirical Study on Electricity Company in Indonesia
}

\author{
M. Ahsin Sidqi, Asep Hemawan, Zainal \\ willy.arafah@gmail.com
}

\begin{abstract}
This study examines the influence of innovation strategies and the role of learning organization to the performance of PLN business units. The dimensions of innovation strategy are (1) entrepreneurial leadership, (2) process innovation (3) service innovation and (4) learning organization as mediation to improve business unit performance. Business units of PT. The questionnaire consisted of 42 questions of choice with five Likert scales and one open question for analysing the 5 latent variables of the study. Data processing using SPSS 19 and SEM with software application LISREL Version 8.8.

The findings of this research is the role of learning organization and entrepreneurial leadership to innovation is a source of knowledge and new capabilities and can produce more quality and sustainable innovation that will ultimately improve business unit performance. This study also proves the positive effect of sustainable innovation strategies will improve performance. Proven business unit performance is influenced by itself or together by innovation factor of entrepreneurial leadership, process innovation, service innovation and mediated with learning organization. Variable learning organization has the most dominant influence on performance. This study shows that positively improving the effectiveness of innovation strategies and learning organization will result in improved performance.
\end{abstract}

Keywords: Innovation strategy, Service innovation, process innovation, Entrepreneurial leadership, Learning organization, Performance.

\section{INTRODUCTION}

Entrepreneurship Leadership: Is a combination of entrepreneurial characteristics that focus on exploiting opportunities to gain added value with leadership behaviors that focus how to influence others. The role of a leader in a business unit in order to have the capacity to create innovations in order to compete with an uncertain environment through new transactional conceptions and realizations. (Gupta and Mac Millan, 2001).

Service Innovation: New concepts in customer interactions and channels, service delivery, individual technology concepts that enhance human and organizational capabilities (Van Ark, 2003).

Process Innovation: New production methods, management approaches and technologies to improve production and streamline management processes (Wang and Ahmed, 2004).

Learning Organization (LO): Is an organization that learns collectively and passionately, and constantly transforms itself to the collection, management, and use of better knowledge for the success of the company (Marquardt, 2002).

Company Performance: A full view of the company over a certain period, is the result or achievement that is influenced by the company's operational activities in utilizing its own resources (Helfert, 1996).

Dynamic Capability (DC): The ability of management to adapt, integrate, and configure precisely internal and external organizational skills, resources and functional competencies to adapt to environmental change. The 
Sustainable Innovation Strategy and Role of Learning Organization in Improving Business Unit Performance Empirical Study on Electricity Company in Indonesia

term dynamic demonstrates the capacity to renew organizational competencies in order to achieve conformity with changes in the business environment (Teece et al, 1997).

Sustainable Competitive Advantage (SCA): The ability acquired through the characteristics and resources of a company to have a higher performance compared to other companies in the same industry or market. (Porter, 1985).

\section{Previous Research}

Strategic management as a tool to create sustainable competitive advantage (SCA) or sustainable competitive advantage is significant (Nicolai J. F., 2011). Grant, R.M. (1996) argue that today's strategic management focuses on how companies produce high performance and retain SCA. Management of precise and fast dynamic capabilities of all three components; (1) adaptive ability, (2) ability to absorb and (3) innovative ability is the key to success in applying strategy management (Wang and Ahmed, 2007.)

The latest research on innovation strategies conducted by Hilman, H. and Kaliappen, M. (2015), states that implementation of process innovation and service innovation as a functional strategy helps achieve company performance. It is suggested that further research should be added to the mediator or moderator in the relationship between innovation strategy and company performance. Beyene's research, K.T et al. (2016) about the influence of innovation strategy and innovation implementation with product innovation performance and it is suggested that further research is taken from employee level so that total commitment of member of orgaisasi is more visible.

Table1. Previous research related innovation strategy

\begin{tabular}{|c|c|c|c|c|}
\hline Researcher & $\begin{array}{l}\text { Independent Variable } \\
\text { (Innovation Strategy) }\end{array}$ & $\begin{array}{l}\text { Dependent } \\
\text { Variable }\end{array}$ & Market & $\begin{array}{l}\text { Mediating } \\
\text { Variable }\end{array}$ \\
\hline $\begin{array}{l}\text { Hilman, H . and } \\
\text { Kaliappen (2015) }\end{array}$ & \begin{tabular}{|l|} 
Proces Innovation \\
Service Innovation
\end{tabular} & $\begin{array}{l}\text { Operational } \\
\text { performance }\end{array}$ & Hotel & - \\
\hline $\begin{array}{l}\text { Karlsson, C. and } \\
\text { Tavassoli, S. (2015) }\end{array}$ & \begin{tabular}{|l|} 
Process innovation \\
Product innovation \\
Marketing innovation \\
Organizatonal innovation \\
\end{tabular} & Performance & Corporate & $\begin{array}{l}\text { Labour } \\
\text { productivity }\end{array}$ \\
\hline $\begin{array}{l}\text { Beyene, K.T. et. al. } \\
\text { (2016) }\end{array}$ & $\begin{array}{l}\text { Technology push } \\
\text { Market pull }\end{array}$ & $\begin{array}{l}\text { Product } \\
\text { innovation } \\
\text { performance }\end{array}$ & $\begin{array}{l}\text { Manufacture } \\
\text { industry }\end{array}$ & $\begin{array}{l}\text { Organizational } \\
\text { learning }\end{array}$ \\
\hline $\begin{array}{l}\text { Torres, I.T, et. al. } \\
\text { (2016) }\end{array}$ & $\begin{array}{l}\text { Innovativeness } \\
\text { Capacity to innovative } \\
\text { Organizational learning } \\
\end{array}$ & $\begin{array}{l}\text { Organizational } \\
\text { Performance }\end{array}$ & Corporate & Strategic Fit \\
\hline These reseach & $\begin{array}{l}\text { Entrepreuneal leadership } \\
\text { Process Inovation } \\
\text { Service Innovation }\end{array}$ & Performance & $\begin{array}{l}\text { Electricity } \\
\text { generation }\end{array}$ & $\begin{array}{l}\text { Learning } \\
\text { organization }\end{array}$ \\
\hline
\end{tabular}

\section{Gaps In Reseacrh}

Based on literature study, this study found the gap of research as follows: (1) Organizational failure to achieve excellence is caused by failure in innovation implementation, the influence of functional strategies (productivity, innovation, technology, marketing, organizational and financial strategy) on the competitiveness of firms which is demonstrated by company performance (Achua, CA and Robert, N . 2010) (2) Implementation of process innovation and service innovation as a functional strategy helps achieve company performance and is suggested in subsequent research by adding new mediators or moderators (Hilman, H. and Kaliappen, M. 2015) (3) No 
Sustainable Innovation Strategy and Role of Learning Organization in Improving Business Unit Performance Empirical Study on Electricity Company in Indonesia

empirical research has been found that investigates innovation as a source of new knowledge that can affect the learning organization and impact on performance (4) There are many research innovation strategy done but have not found research on energy world context, especially electricity power.

\section{Sustainable Innovation Engine}

According to De Sousa, C.M. (2009), having a profound level of knowledge is important to innovate, as it can increase the level of new understanding and opportunities, but also the ability to bring new useful ideas. If an organization does not guarantee a diversity of knowledge, innovation may tend to be narrow and focuses only on continuous improvement as it is usually tied to the context and perspectives of experts working on clearly identified user needs. A better diversity of knowledge will encourage different synergies, often from different contexts, creating a leap to a higher level of creativity than the old thinking habits (Out of the Box). Therefore, the diversity of knowledge as an effort to disseminate different areas of knowledge within an organization can be stimulated by members of the organization, and can also be achieved through external knowledge (De Sousa, C.M., 2009).

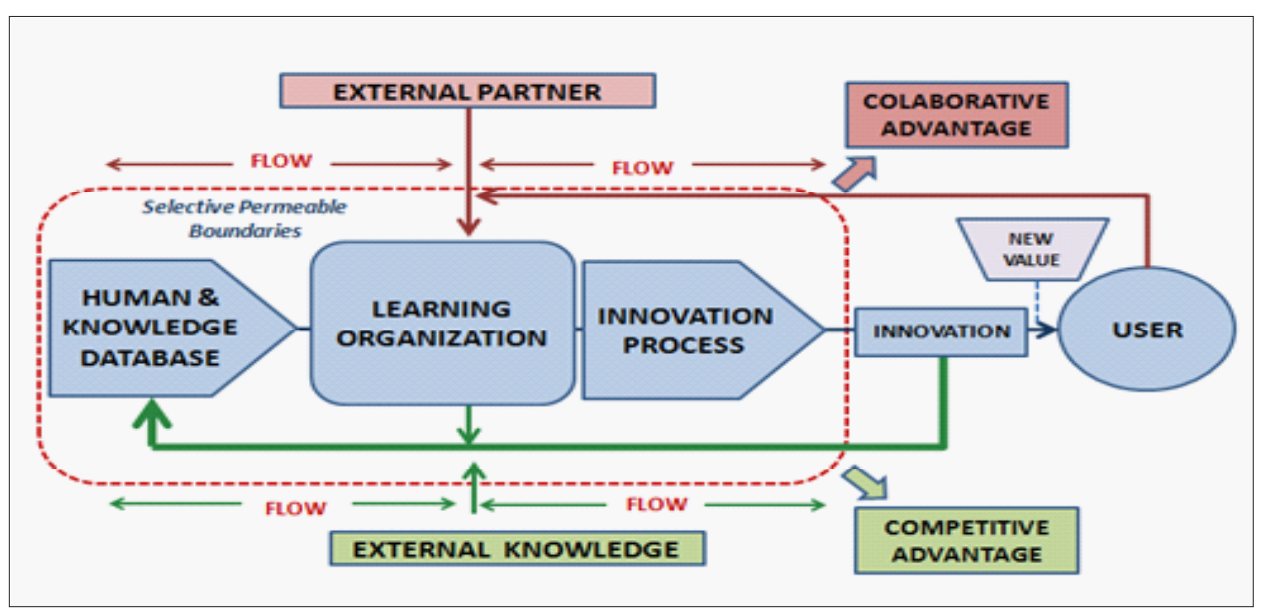

Figure1. Sustainable innovation engine (De Sousa, C.M. 2009)

\section{Conceptual Framwork}

Gupta and MacMillan (2001) revealed that entrepreneurial leadership is the role of a leader in a business unit, having the capacity to create process innovations in order to compete with an uncertain environment through conception and new transactional realization. From the description above can be prepared hypothesis; Hypothesis 1: Entrepreneurial leadership has a positive effect on Process Innovation

Bryd and Bryman (2003) say that there are two dimensions underlying innovative behavior that is creativity and risk taking. So it is with opinion (Jong, D and Kamp, 2003) that all innovation begins from creative idea. Creativity is the ability to develop new service ideas consisting of three aspects: keahilan, flexible and imaginative thinking ability and internal motivation (Bryd and Bryman, 2003). From the description above can be prepared hypothesis Hypothesis 2: Entrepreneurial Leadership has a positive effect on Service Innovation.

Marquardt (1996) identifies six leadership roles in organizational learning. He considers roles as: instructors, trainers and mentors as the most important aspects of leadership in learning organizations. In the role of being a knowledge manager, co-learners and models for learning. Leaders are self-learner, As architects and designers and coordinators, they are responsible for creating a learning environment that motivates followers to do their best Hypothesis \#3: Entrepreneurial leadership has a positive effect on learning organization.

Scott and Venkataraman (2000) state the importance of identifying profitable opportunities for growth in 
Sustainable Innovation Strategy and Role of Learning Organization in Improving Business Unit Performance Empirical Study on Electricity Company in Indonesia

practice. Future views are the ability to identify future opportunities or about future market changes, integrate all views and then try to create strategies that affect outcomes (Grant, 1996).). In addition to the foresight, employers should be able to determine what resources are needed to realize identifiable business opportunities. It is called the leader's insight that is the ability to integrate internal resources that respond to opportunities effectively and efficiently (Sambamurthy et al, 2003). Hypothesis \# 4: Entrepreneurial leadership has a positive effect on Performance.

Sustained innovation is achieved by successfully managing positive feedback that stimulates innovation, through sharing and creating knowledge and using new knowledge generated from innovation to feed into the organizational knowledge base. The consequences of failing to manage this process effectively can be disastrous (De Sousa 2009).:Hypothesis \#5: Process innovation has a positive effect on learning organization.

Laiponen, A. (2005) states that sustainable process innovation is a synthesis of accumulated knowledge, leading to corporate growth and financial performance. Continuous innovation changes the existing service system. Companies must improve their services and products dynamically to maintain their competitive advantage (Smeds and Boer, 2004). From the description above can be prepared hypothesis: Hypothesis \#6: Process Innovation positively affects performance.

The consequences of not managing this process effectively will be disastrous. For example, the mortality rate of small innovative companies that often launch innovative and first successful products but can not use new knowledge created to further innovate and ensure sustainable growth. These companies are often out of business long after their first product fades (De Sousa, M.C. 2006). From the description above can be prepared hypothesis: Hypothesis \#7: Service has a positive effect on learning organization.

Innovation in learner orgasization will be faster implemented with faster learning process and to achieve the overall corporate strategy advantage and Total Qulaity Managemet movement in learning organization that carry out continuous innovation will get competitive power. (Marquardtr, 1996). From the description above can be prepared hypothesis: Hypothesis \#8: Service Innovation positively affects performance.

The application of LO concept to business organization has been done in developed countries (Marsick and Watkins, 2003), and variousstudies have been conducted to seetheinterrelation and impactbetween LO on various aspects of organizational behavior such as job satisfaction, work commitment and organizational performance can improve company performance. From the description above can be prepared hypothesis:Hypothesis \#9: Learning organization has a positive effect on performance.

Based on previous literature and research, innovation strategies are among others (1) entrprneurial leadership; (2) process innovation and (3) service innovation will affect the learning organization and ultimately will affect the company performance.

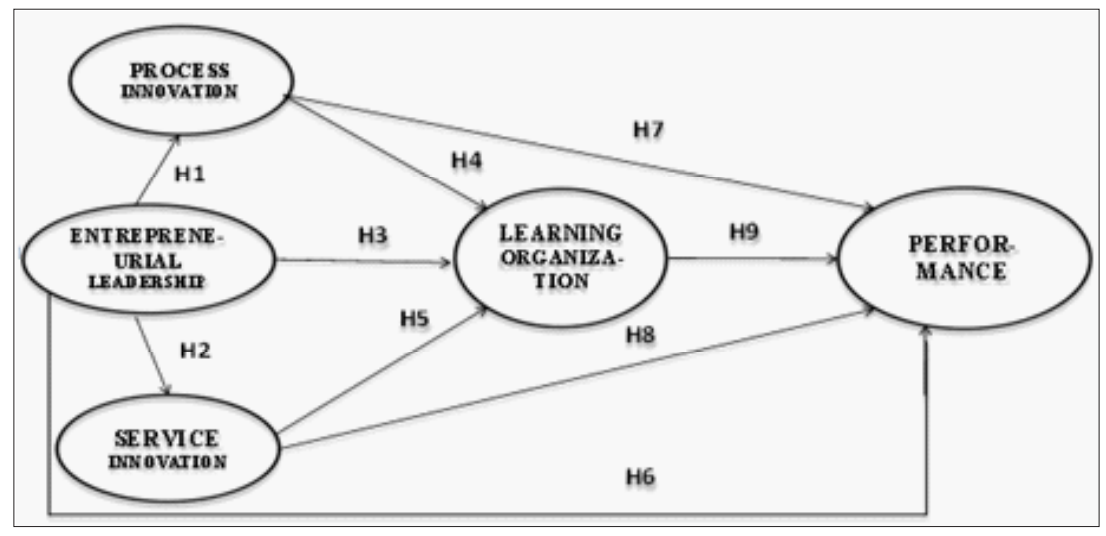

Figure2. Concept research model 
Sustainable Innovation Strategy and Role of Learning Organization in Improving Business Unit Performance Empirical Study on Electricity Company in Indonesia

\section{METHODE}

\section{Research Design}

This study aims to test the hypothesis of the influence of innovation strategy that consists of entrepreneurial leadership, process innovation, service innovation with the mediation of learning organization influence on unit bisinis performance. This study uses explanatory research causality describes a relationship between variables through hypothesis testing or called hypotheses testing test Sekaran and Bougie, (2010)

Variables measured using Likert scale. The Likert scale is used to measure attitudes, opinions of numbers 1 to 5 with the notion $1=$ strongly disagree and $5=$ strongly agree to both Sekaran and Bougie, (2010). The data obtained, processed and analyzed by using analysis tool Structural Equation Modeling (SEM) LISREL software version 8.80 .

\section{Variable Measurement}

\section{Variables, Dimensions and Indicators of Entrepreneurial Leadership}

Entrepreneurial leadership is measured by parameters compiled from research Gupta et al., (2004) with two main roles that will be faced by entrepreneurial leaders namely; cast enatcment and transsformational enactment. Both roles are influenced by the five specific role adapted and modified entrepreneurial leadership of McGrath and MacMillan (2000) and Gupta et al. (2004). This model has also been tested on 60 more commuities incorporated in the global leadership and organizational behavior effectiveness program (GLOBE) with 13000 middle management members from 1995 to 1997.

\section{Process Innovation Variables, Dimensions and Indicators}

Service innovation is evaluated and measured using parameter items derived from Grawe et al., (2009) and Hilman H. and Kaliapen N. (2015). Respondents were asked to state the condition and implementation of functional strategy of process innovation. Process innovation emphasizes the creation of improved techniques, knowledge, processes, systems, procedures and skills to transform the service creation process.

\section{Service Innovation Variables, Dimensions and Indicators}

Service innovation was evaluated and measured using parameters taken from Grawe et al., (2009) and Hilman H. and Kaliapen N. (2015) studies. Respondents were asked to state the conditions and implementation of service innovation functional strategies undertaken by employees and companies they work

\section{Learning Organization's Variables, Dimensions and Indicators}

Learning organization is measured by taking from Watkins and Marsick's research, (2003), which is structured as a dimension of learning organization questionnare (DLOQ). Some components, such as leadership, learning processes and other systematic support factors, are ascertained in seven indicators: (1) continuous learning (2) inquiry and dialogue (3) team learning (4) embedded systems (5) empowerment (6) system connection (7) trategic leadership.

\section{Variables, Dimensions and Performance Indicators}

A company's performance can be measured with both financial and non-financial perspectives (Kaplan and Norton, 1996). The company's most commonly used company performance is to maximize profits by utilizing resources more efficiently and effectively. Arifin, Z. (2016) stated that business unit performance can be 
Sustainable Innovation Strategy and Role of Learning Organization in Improving Business Unit Performance Empirical Study on Electricity Company in Indonesia

simplified into two things, namely; financial and non-finacial that describe the characteristics of business unit performance, namely; efficiency, productivity and agility.

\section{Respondence and Sample}

The questionnaires were distributed to 444 units of PLN business (consisting of 426 units of PLN business and 28 units of subsidiary business unit) and the incoming data was 232 questionnaires or $52.25 \%$. From the incoming data is selected. There are 18 respondents who come from the same business unit, and 4 respondents who are not feasible or incomplete filling, so that obtained data 210 which for further processing and analysis. The percentage of incoming questionnaires is $52.25 \%$ in this number is already very good compared with the rate of return of the management survey straregik which ranges from 20\% to 25\% (Morgan \& Strong, 2003).

\section{Testing of Research Instruments}

The data obtained is checked first the validity and reliability. Based on the number of samples used, the indicator used will be valid if the minimum loading factor value is 0.35 (Hair, et al., 2010). A questionnaire is said to be reliable if the respondent's answer to the question is consistent from time to time by looking at the Cronbach's Alpha.

\section{Data Analysis Method}

Univariat analysis was used to analyze each variable used in this study by calculating central tendency through mean / mean. While multivariate analysis is done to test the hypothesis and in this research using stuctural equation modeling (SEM) processed by using LISREL program version 8.80 .

\section{Hypothesis Testing With Stuctural Equation Model (SEM)}

A complete SEM modeling basically consists of a measurement model and a structural measurement model intended to confirm a dimension or factor based on its empirical indicators. Structural models are models of relationship structures that form or explain causality between factors.

After data collected and data reception is stopped, data analysis begins. Data analysis methods obtained through the spread of valid and reliable questionnaires will then be performed data analysis techniques using SEM (structural equation modeling) is done by using computer program (software) LISREL version 8.80. Structural equation modeling (SEM) is a statistical model that provides approximate calculations of the strength of the hypothesis relationships among variables in a theoretical model, either directly or through intermediate (intervening or mediating) variables. The process of data analysis is done as follows:

\section{Pre-test Conditioning}

Conducted after the research proposal was approved, the FGD was conducted with a business unit unit around Jakarta with the purpose of observing the validity of questions in the survey.

\section{Measurement Analysis Model}

With 3 phases of implementation; (1) the overall fit test of the model by calculating the goodness of fit index (GOFI) value, (2) the validity analysis, and (3) the reliability analysis. The GOI of the model is based on the comparison of the calculation and the standard value. After obtaining the GOFI value of the model, the next step 
Sustainable Innovation Strategy and Role of Learning Organization in Improving Business Unit Performance Empirical Study on Electricity Company in Indonesia

is to test the validity of the measurement model. Wijayanto (2008) states that a good validity indicator for latent variables is if they have: (1) T-value> 1.96 (2) Standardized loading factor (SLF) > 0.50.

\section{Testing Validity, Reliability and Constructive Conformity}

The main purpose is to test the indicators that have been grouped by their latent variables (constructs) whether the indicators are consistent in the construct or not. This stage tests whether the fit with the model was formed before or not. Testing the validity and reliability of constructs using confirmatory factor analysis (CFA) and secondary confirmatory factor analysis (SOCFA). For process innovation variables, service innovation and performance testing are performed with CFAs because measurement indicators are only four to six. For vairabel entrepreneurial leadership and learning organization testing using SOCFA due to more measurement indicator items with different number of dimensions and indicators, in accordance with the opinion of Sekaran, (2003).

Table3. Overall index suitability of the model

\begin{tabular}{|c|c|c|c|}
\hline GOF Indicator & Parameters & Estimation & Conclution \\
\hline \multicolumn{5}{|c|}{ Absolute Fit } \\
\hline RMSEA & RMSEA $\leq 0,08$ & 0,042 & Good fit \\
\hline Incremental Fit \\
\hline NFI & NFI $\geq 0,90$ & 0,98 & Good fit \\
\hline NNFI & NNFI $\geq 0,90$ & 0,99 & Good fit \\
\hline CFI & CFI $\geq 0,90$ & 0,99 & Good fit \\
\hline IFI & IFI $\geq 0,90$ & 0,99 & Good fit \\
\hline RFI & RFI $\geq 0,90$ & 0,97 & Good fit \\
\hline Std. RMR & Std. RMS $<0,05$ & 0,033 & Good fit \\
\hline GFI & GFI $\geq 0,90$ & 0,92 & Good fit \\
\hline AGFI & AGFI $\geq 0,90$ & 0,93 & Good fit \\
\hline
\end{tabular}

Based on Table 3 above, there are six conformity index of the model obtained have good fit model index (good fit), that is: RMSEA, NFI, NNFI, CFI, IFI, RFI, GFI and AGFI. Thus it can be continued on the next analysis.

\section{Structural Equation Model}

Next will be presented full model SEM parameter testing $\lambda$ (loading factor / coefficient indicator) measurement on exogenous and endogenous models. This test is intended to determine whether or not the indicators of each latent variable (construct).

This analysis measures the $t$-value and coefficients of structural equations. By testing the $t$-value is greater than 1.96. For t-value value of coefficient / parameter and coefficient / parameter value (estimation) can be seen in the following figure. In result of data analysis by using method of Structural Equation Model (SEM) and by using tool processing software application LISREL version 8.80 hence obtained summary index of suitability model as in Table below: 
Sustainable Innovation Strategy and Role of Learning Organization in Improving Business Unit Performance Empirical Study on Electricity Company in Indonesia

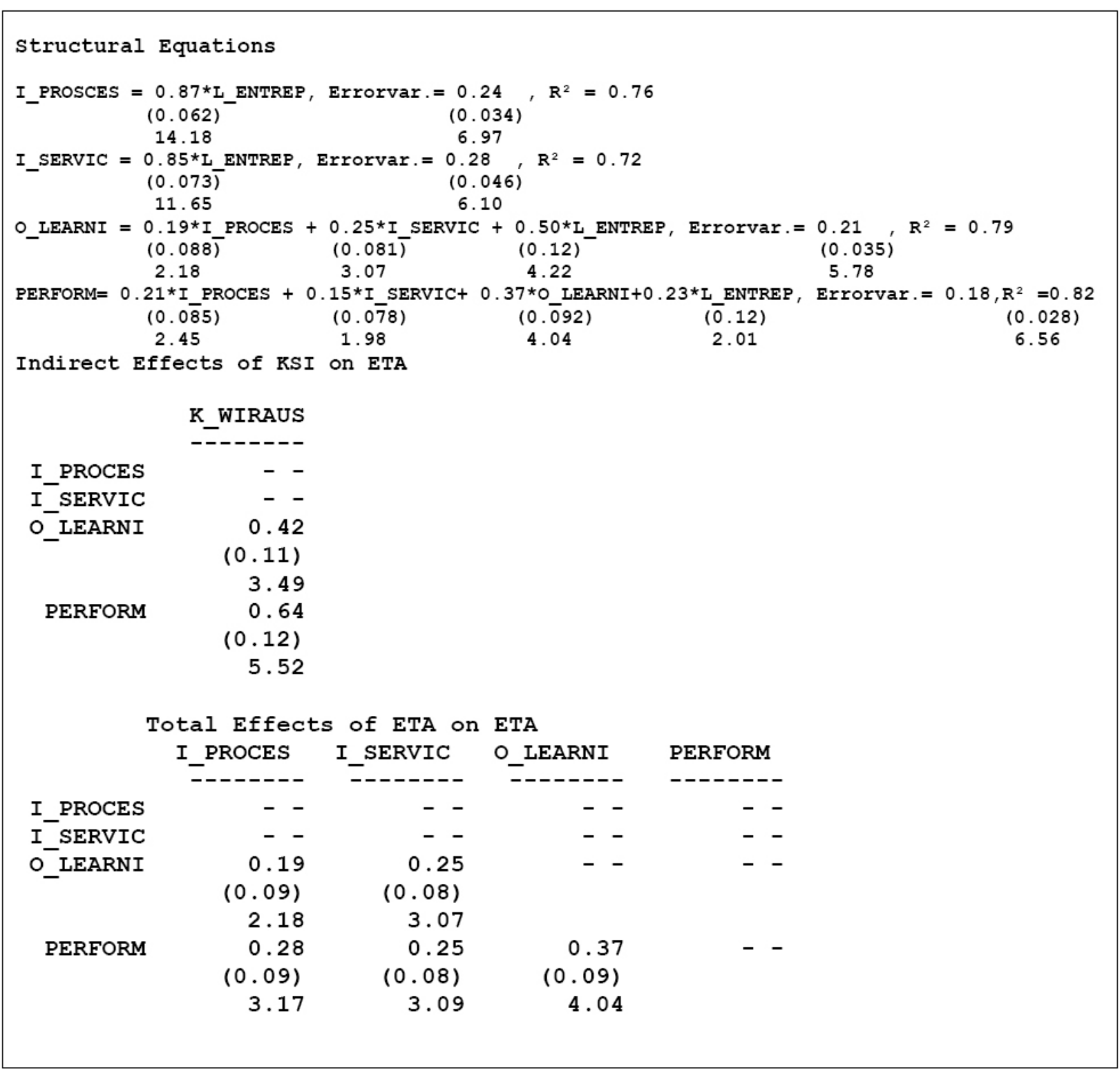

Figure3. Structural equation model of research

\section{RESULT}

\section{Hypothesis Testing Anda Hypothesis Analysis Method}

Fixed analysis tool used: The analyzer selected is SEM LISREL version 8.80. Determination of significance level. The significance level in this study was 0.05 or $5 \%$. The basis of decision making on hypothesis testing is to calculate good validity number for latent variable if it has t-value $>1.96$, coefficient value or parameter is a predetermined value used as comparator of $t$-value to test hypothesis from research.

\section{Hypothesis Testing Results}

The results of hypothesis testing obtained by using SEM LISREL version 8.80 are shown in table as follows: 
Sustainable Innovation Strategy and Role of Learning Organization in Improving Business Unit Performance Empirical Study on Electricity Company in Indonesia

Table4. Results of hypothesis testing

\begin{tabular}{|c|c|c|c|c|}
\hline \multicolumn{2}{|c|}{$\begin{array}{c}\text { Hiyphotesises } \\
\text { H1 }\end{array}$} & $\begin{array}{c}\text { Standardized } \\
\text { path coefficient }\end{array}$ & t-value & Result \\
\hline H2 & $\begin{array}{c}\text { Entrepreneurial leadership has an effect on } \\
\text { process innovation }\end{array}$ & 0,87 & 14,18 & Supported \\
\hline H3 & $\begin{array}{c}\text { Entrepreneurial leadership has an effect on } \\
\text { service innovation }\end{array}$ & 0,50 & 4,22 & Supported \\
\hline H4 & $\begin{array}{c}\text { Process innovation affect the learning } \\
\text { organization }\end{array}$ & 0,19 & 2,18 & Supported \\
\hline H5 & $\begin{array}{c}\text { Service innovation affect the learning } \\
\text { organization }\end{array}$ & 0,25 & 3,07 & Supported \\
\hline H6 & $\begin{array}{c}\text { Entrepreneurial leadership has an effect on } \\
\text { performance }\end{array}$ & 0,23 & 2,01 & Supported \\
\hline H7 & Process innovation has an effect on performance & 0,21 & 2,46 & Supported \\
\hline H8 & Service innovation has an effect on performance & 0,15 & 1,98 & Supported \\
\hline H9 & $\begin{array}{c}\text { Learning organization has an effec on } \\
\text { performance }\end{array}$ & 0,37 & 4,04 & Supported \\
\hline
\end{tabular}

\section{Theoretical Implications}

The findings of this study provide theoretical contributions by enriching the antecedents of performance, which adds entrepreneurial leadership constructs as part of the innovation strategy and adds a learning organization mediation that positively and significantly affects performance. The addition of construct entrepreneurial leadership and learning organization is possible because together with innovation is an important part of resources in dynamic capability.

Unlike previous studies, this research takes innovation strategy with variable of proscess innovation, service innovation and entrepreneurial leadership by using mediation of learning organization and its effect on performance. Until now there has been no empirical research on the role of variable mediation learning organization in the strategy of continuous innovation and its influence on performance, moreover in the electrical sector.

\section{Managerial implications}

The results of this study found that there is a positive influence entrepreneurial leadership, process innovation and service innovation to the learning organization and implicate the performance of electricity companies in Indonesia. The managerial implications of the research can be described as follows: (1) The mediating effectiveness of the learning organization can enhance the influence of entrepreneurial leadership, innovation and innovation process innovation on performance by: more supportive and accepting management and innovation, always looking for ways to improve customer service, giving service innovation in service internal or external, (3) Increasing the role of simultaneously entrepreneurial leadership, process innovation, service innovation and learning organization on performance can be done by way of; the unit manager inspires employees to be motivated to work hard, improves sustainable performance, passes on positive and strong morale, designs systems / methods of work with more speed with better quality. Perfected a working method 
Sustainable Innovation Strategy and Role of Learning Organization in Improving Business Unit Performance Empirical Study on Electricity Company in Indonesia

for ease of service process. Always looking for ways to improve customer service, paying attention to service innovation in services both internal and external, and in working, fellow employees trust each other. Benefits of managing community of practice, knowledge sahring on knowledge management in business unit more dirasakandan and employee initiative appreciated.

For the government;(1) Can create policies to encourage entrepreneurship culture and learning organizationbased innovation, in all well-managed sectors to strengthen the nation's competitiveness (2) Government policies are needed in the form of roadmaps and incentives that support sustainable innovation strategies in order to anticipate both in terms of technology, systems, competencies, services and regulations to be more adaptive to change in the current disruption era.

For the company: (1) Implementation of sustainable innovation strategy, through strengthening and development of learning organization, so that business units are more efficient in managing resources to increase productivity, and lower production cost in the long term. (2) Employee appraisal in addition to achievement of performance is more emphasized also on the development of knowledge through innovation, creativity and contribution of knowledge at national and international level. The company will achieve a faster vision if not only busy with routine things but also support the birth of new innovations by providing the tools and resources, the atmosphere of safe, comfortable and the freedom to innovate.(3) Realizing business unit performance will be sustainable if managers can retain the already good and improve the role that is still lacking. The manager's role is already good at; (a) the role of technical (b) has demonstrated the performance through process innovation well (c) the service has been done well on all the customers (d) mutual trust has become a good foundation for the implementation of the program. (4) The role of unit manager must improve; (a) more entrepreneurship role so that participation in active employees in innovation can continue to be done (b) must be creative to update with appropriate policy (c) must be updated regularly according to customer wishes (d) must learn many things and varied for optimization and an invasion update according to company needs (e) the frequency of reliability-related disturbances should be more noticed.

\section{Limitations of Research}

This study is inseparable from some limitations, especially time and variable and respondents, is expected to be a recommendation for future research related innovation strategy when the role of innovation leads to disruption era. Limitations in this study include the following: (1) This study only discusses the variables related to dynamic capabiliy (Wang, Ahmed (2007) straetgi innovation (entrepreneurial leadership, process innovation, service innovation) with mediation learning organization that affect the performance ) (2) This research stretegi innovation at the level of individuals, business units and venture.

\section{Suggestions For Further Research}

Based on the findings of empirical research obtained, the authors convey some suggestions (1) The variables of innovation strategies in future research can be derived from Schlumpeterian (process, product and market) or technology-related innovation strategies include; product, service and process (Miller, et al., 2007) with stretegic orientation mediation such as technology, customers and competition with other dependent variables such as competitive advantages. (2) It can be investigated more deeply the correlation of innovation strategy with the tendency of exploiting open innovation (Chesbourgh, H. 2014) or social innovation (De Sousa, 2016) so as to respond to the challenges and needs of companies in disruption era

\section{REFERENCES}

Achua A. C and Lussier R. N. (2010), “Effective leadership 4th Editions”, South Western, Ohio.

Arifin, Z, Fontana, A (2016)"19 Tahun Inovasi, Ketenaga listrikan Indonesia PLN. Berinovasi untuk Indonesia," PLN research Institut, Jakarta.

American Research Journal of Business and Management

Page 10 
Sustainable Innovation Strategy and Role of Learning Organization in Improving Business Unit Performance Empirical Study on Electricity Company in Indonesia

Arifin, Z. (2015), "The determinat factors of technology adoption for improving business units performance, an empirical research of Indonesia electricity company" Disertation Faculty of Economics and Business Graduate School of Management, University Of Indonesia

Barney, J. (1991), “Firm resources and sustained competitive advantage”, Journal of Management, Vol. 17 No. 1, pp. 99-120.

Byrd, J. and Brown, P.L. (2003), "The innovation equation : Building creactivity and risk taking” Jossey-Bass, San Francisco

Cohen, W.M. and Klepper, S. (1996)" Firm size and nature of innovation within industries : the case of process and product R \& D" The Revew of Economic and Ststistics, Vol.79, No.2, pp. 232-243.

Chesbrough, H., \& DiMinin, A. (2014). “Open social innovation. In H. Chesbrough, W. Vanhaverbeke, \& J. West (Eds.), New frontiers in open innovation" Oxford: Oxford University Press.,pp. 169-188).

Christensen, C. M. (1995) “ The Innovators's dilemma : when new technologies coause great firms to fail” Harvard Business School Press, Boston, MA

De Sousa, M.C. (2006) "The sustainable innovation engine", Journal of Information and Management System, Vol.34 No. 6 pp. 389-405.

Drucker, P. (1986), “ Innovation and Entrepreneurship”, Perennial Library, New York.

Farruch. M. (2015) ," Learning organization and competitive advantages", Journal of Asian Business Strategy Vol. 5 No.4, pp.73- 79.

Grant,R.M., (1996) "Toward a knowledge based theory of the firm" Stretegic Management Journal, Vol. 17, Winter special issue pp. 109-122

Grawe, S., Chen, H. and Daugherty, P. (2009), "The relationship between strategic orientation, service innovation on performance", International Journal of Physical Distribution andLogistics Management, Vol. 39 No. 4, pp. 282-300.

Gupta, V, Mac Millan, I. C, and Suriec G (2004), "Entrepreneual leadership; developing and measuring a crosscultural contruct", Journal of Business venturing Vol 19, No. 2, pp.241-260.

Helfert, E.A. (1996), "Techniques of financial analysis : A practical guide to measuring business performance 9'th edition" Irwin Professional, IL. Chicago.

Hilman H. and Kaliappen, N., (2015) "Innovation strategies and performance: Are they truly linked?", World Journal of Enterpreneurship, Managment and Sustainable Development, Vol.11 No.1, pp. 48-63.

Kaplan, R.S. and Norton, D.P. (1996), "The Balanced Scorecard: Translating Strategy into Action",HBS Press, Boston, MA.

Kotter, J. P. (1990). "A force for change: How leadership differs from management" Free Press, New York.

Lopez, A.M.M. and Sanchez, A.A.V. (2013), "The strategic management process and the innovative capacity of the Spanish hotel industry", Journal of Hospitality Marketing \& Management, Vol. 22 No. 6, pp. 596-618.

Marquardt, Michael J. (2002) "Building The Learning Organization: Mastering The 5 Elements for Corporate Learning", 2nd Edition, CA: Davies-Black Publishing.

Marquardt, Michael J. (1996) "Building the Learning Organization: - A Systems Approach to Quantum Improvement" McGraw-Hill,

American Research Journal of Business and Management

Page 11 
Sustainable Innovation Strategy and Role of Learning Organization in Improving Business Unit Performance Empirical Study on Electricity Company in Indonesia

Miller, D.J., Fern, M.J. and Cardinal, R.B. (2007), "The use of knowledge for technological innovation within diversified firms", Academy of Management Journal, Vol. 50 No. 2, pp. 308-326.

Nicolai J.F, "Entrepreneurship in the context of the resources based vew of the firm" Dept of Strategic Management and Globalization Copenhagen Business School, 2011.

Porter, M.E. (1981) "The contribution of industrial organization to strategic management". Academy of Management Review.

Rosengarten, P.G.(1999), "The characteristic, outcomes and sorce of the learning orgaization, the case of car component supplier in britai", The London School of ecnomic.

Rumelt, R.P., Schendel, D and Teece, D., (1991), "Foundamental isssue in strtegy" Harvard Business School Press Cambridge.

Schumpeter, J.A. (1934),"The theory of economic development, $2^{\text {nd }}$ edition", Cambridge Harvard University Press.

Scott J. G; Chen H. Patricia J. D. \& (2009), "The relationship between strategic orientation, service innovation, and performance International”, Journal of Physical Distribution \& Logistics Managemen, Vol. 39 No. 4,pp. 282-300.

Senge, P.P. (2004), “The leader new work: Building learning organization How Organizations learn", Managing the Search for knowledge. pp 462-486.

Teece, D.J., Pisano, G. and Shuen, A. (1997), "Dynamic capabilities and strategic management",Strategic Management Journal, Vol. 18 No. 7, pp. 509-533.

Tsang, W. K. (1997). "Organizational Learning and the Learning Organization: A Dichotomy Between Descriptive and Prescriptive Research" Human Relation Journal (HRJ), Vol.50, pp. 73-89.

Victorino, L., Verma, R., Plaschka, G., \& Dev, C. (2005).,"Service innovation and customer choices in the hospitality industry". Managing Service Quality, Vol.15 No. 6, pp.555-576.

Wang, C.L and Ahmed P.K. (2004) " The Development and Validation of the Organisational Innovativeness Construct Using Confirmatory Factor Analysis “,European Journal of Innovation Management, Vol.7, No.4, pp. 303-313.

Wiig, K. (1993), "Knowledge management foundations - thinking about thinking - How people and organizations create, Represent and use knowledge", Schema Press, Arlington, VA.

Citation: M. Ahsin Sidqi, Asep Hemawan, Zainal. "Sustainable Innovation Strategy and Role of Learning Organization in Improving Business Unit Performance Empirical Study on Electricity Company in Indonesia" American Research Journal of Business and Management. 2018; 4(1): 1-12.

Copyright (C) 2018 M. Ahsin Sidqi, Asep Hemawan, Zainal. This is an open access article distributed under the Creative Commons Attribution License, which permits unrestricted use, distribution, and reproduction in any medium, provided the original work is properly cited. 